\title{
PENERAPAN DIALOGICAL ARGUMENTATION INSTRUCTIONAL MODEL (DAIM) UNTUK MENINGKATKAN PEMAHAMAN DAN KEMAMPUAN ARGUMENTASI SISWA SMA PADA MATERI LISTRIK STATIK
}

\author{
A. Nuryandi*, D. Rusdiana \\ Program Studi Pendidikan Fisika, Sekolah Pascasarjana \\ Universitas Pendidikan Indonesia \\ Email Korespondensi: nuryandie@gmail.com*
}

\begin{abstract}
ABSTRAK
Penelitian ini bertujuan untuk mengetahui peningkatan kemampuan memahami dan argumentasi siswa SMA sebagai efek pembelajaran menggunakan Dialogical Argumentation Instructional Model (DAIM). Penelitian dilakukan terhadap siswa SMA Kelas XII di salah satu SMA di Kabupaten Majalengka menggunakan metode preexperiment dengan desain one group pretest-posttestdesign. Instrumen yang digunakan adalah tes pemahaman dan kemampuan argumentasi siswa, tes lisan, serta observasi dan wawancara. Hasil penelitian menunjukkan terjadi peningkatan kemampuan memahami siswa dari persentase skor rata-rata $30,16 \%$ menjadi $72,81 \%$ dengan nilai persentase $\mathrm{N}$-gain sebesar $61,36 \%$ atau pada kriteria sedang dan peningkatan kemampuan argumentasi siswa dari persentase skor rata-rata $27,12 \%$ menjadi $72,07 \%$ dengan nilai N-gain sebesar $62,01 \%$ atau pada kriteria sedang. Berdasarkan tanggapan siswa, model ini membuat mereka lebih merasa tertantang untuk berpikir, melakukan kegiatan diskusi lebih baik, pemahaman siswa terhadap materi lebih mendalam, serta memiliki kepercayaan diri dalam berkomunikasi ilmiah menggunakan bukti dan alasan. Penerapan DAIM dalam penelitian ini hanya dilakukan dua pertemuan, disarankan penelitian lebih lanjut melakukan pertemuan lebih banyak lagi untuk meningkatkan efektivitasnya.
\end{abstract}

Kata kunci: DAIM, pemahaman, kemampuan argumentasi

\section{ABSTRACT}

This study aims to enhance students' understanding and ability argumentation of high school students as the effects of learning using Dialogical Argumentation Instructional Model (DAIM). Research conducted on high school students in one of the Class XII High School in Majalengka using the pre-experiment with one group pretestposttest design. The instrument used was a test of student understanding and ability of argumentation, verbal tests, as well as observation and interviews. The results showed an increase of the percentage students' understanding of the average score of $30.16 \%$ into $72.81 \%$ with a value of $\mathrm{N}$-gain of $61.36 \%$ or middle category and increase of the percentage the ability of argumentation students from an average score of $27.12 \%$ into $72.07 \%$ with $\mathrm{N}$-gain value of $62.01 \%$ or middle category. Based on student responses, these models make them feel challenged to think, do a better discussion activities, students' understanding of the topics in more depth, and have confidence ini communicating scientific use of evidence and reason. Applitacion of DAIM in this study only two treatments, further research suggested more treatment to improve its effectiveness.

Keyword: DAIM, understanding and ability argumentation

\section{PENDAHULUAN}

Tujuan pembelajaran fisika di SMA menurut KTSP di antaranya adalah menekankan pada penguasaan dan pemahaman konsep dan teori fisika, serta mengembangkan sejumlah keterampilan dan kemampuan berpikir (BSNP, 2006) sebagai bekal siswa di masa yang akan datang.

Hasil observasi di salah satu SMA di kabupaten Majalengka masih terdapat siswa yang kurang aktif dalam kegiatan pembelajaran di kelas. Menurut Kurniawati, dkk. (2014) kurang aktifnya siswa biasanya terjadi pada mereka yang mengalami kesulitan dalam memahami konsep dan mengembangkan kemampuan berpikirnya. Pendapat Kurniawati ini didukung dengan hasil ujicoba tes pemahaman siswa terhadap pelajaran fisika dalam studi pendahuluan diperoleh skor rata-rata sebesar 39,69 untuk skor maksimum 100. Hasil ini 
menunjukkan lemahnya kemampuan siswa dalam memahami fisika.Kostelnikova dan Ozvoldova (2013) mengungkap fakta bahwa pembelajaran seperti itu membuat siswa tidak dapat memahami penjelasan teoritis dari guru, terutama untuk pemahamanpemahaman fisika yang sulit. Pembelajaran tersebut membuat siswa merasa jenuh dan kurang menunjukkan ketertarikan mereka untuk terlibat dalam aktivitas kelas.

Di samping berakibat pada kemampuan memahami siswa yang rendah karena kurang dibiasakan untuk membangun pengetahuan sendiri, strategi pembelajaran yang diterapkan juga belum membekali siswa dengan kemampuan berargumentasi. Dari hasil studi pendahuluan berupa observasi kegiatan pembelajaran di salah satu SMA di kabupaten Majalengka, diketahui bahwa selama proses pembelajaran, siswa kurang mendapatkesempatanuntukmengembangkan kemampuan argumentasinya. Permasalahan yang diberikan kepada siswa selama kegiatan pembelajaran tidak mengarahkan siswa untuk menyusun sebuah klaim, tetapi hanya sebatas pada permasalahan yang mengarahkan siswa pada kegiatan penyelesaian soal secara kuantitatif. Siswa juga tidak mendapat kesempatan untuk memperkuat jawabannya dengan teori atau konsep yang telah diperolehnya, karena penyelesaian masalah atau soal hanya bertujuan sampai menemukan jawaban berupa angka hasil perhitungan. Dengan demikian, dapat diambil kesimpulan bahwa dari aspek-aspek argumentasi, hanya aspek data yang biasa dilatihkan kepada siswa, berupa pengerjaan soal-soal untuk memperoleh angka sebagai jawaban permasalahan. Sedangkan aspek-aspek lain seperti mengajukan klaim, pembenaran, ataupun dukungan, tidak dilatihkan kepada siswa selama proses pembelajaran berlangsung. Berdasarkan hasil ujicoba tes yang digunakan untuk mengukur kemampuan argumentasi siswa dalam studi pendahuluan, diperoleh informasi bahwa skor rata-rata kemampuan argumentasi siswa hanya 27,52 untuk skor maksimum100. Informasi ini menunjukkan bahwa siswa kurang mendapat kesempatan untuk melatih kemampuannya dalam berargumentasi.

Maka diperlukan sebuah upaya perubahan untuk mengembalikan pemahaman bahwa IPA, khususnya fisika yang berkembang saat ini diperoleh melalui proses penyelidikan dan argumentasi yang panjang. Penggunaan argumentasi dengan strategi pembelajaran yang tepat dapat memberikan sesuatu yang lebih dari sekadar mentransfer pengetahuan. Strategi ini dapat mengembangkan berbagai kemampuan siswa seperti kemampuan berkomunikasi, kemampuan penalaran, dan kemampuan berargumen menggunakan bukti (Acar dan Patton, 2012). Untuk itu, salah satu model pembelajaran yang dipandang dapat membantu pemahaman dan kemampuan argumentasi siswa adalah pembelajaran DialogicalArgumentation

Instructional Model (DAIM).

DAIM dikembangkan berdasarkan kerangka argumentasi dari Toulmin's Argumentation Pattern (TAP). Komponen utama dalam TAP adalah kemampuan siswa dalam memberikan pendapat (claim), memberikan dan menganalisis data, pembenaran (warrant), dukungan (backing), serta membuat sanggahan (rebuttal) terhadap permasalahan. Dalam pembelajaran DAIM, kegiatan pembelajaran argumentasi berlangsung pada tahap tugas individu, dialog kelompok kecil, dan keseluruhan kelas. Ogunniyi (2007a dan 2007b) menyatakan bahwa DAIM menyediakan kesempatan yang luas kepada siswa untuk berdebat, membuat klaim atau klaim kontra yang didukung dengan bukti-bukti untuk mempertahankan sikap mereka atau bahkan melakukan sanggahan untuk membatalkan klaim tersebut. Pada akhir pembelajaran, dihasilkan kesimpulan tentang topik permasalahan yang dikemukakan. Dengan begitu, siswa mampu mengekspresikan pandangan mereka secara bebas tanpa merasa terintimidasi, menghapus keraguan mereka, dan bahkan mengubah pikiran mereka apabila keliru (Hlazo dan Ogunniyi, 2014). Sebagai konsekuensi, 
pemahaman siswa terhadap materi fisika dapat diperoleh secara lebih mendalam.

Penelitian Hlazo dan Ogunniyi (2014) melaporkan bahwa hasil tes pemahaman siswa pada materi petir dengan pembelajaran DAIM menunjukkan peningkatan yang secara signifikan lebih tinggi dibandingkan dengan kelas pembanding. Hal ini menunjukkan bahwa siswa yang belajar menggunakan DAIM memiliki pemahaman lebih baik dari pada kelas konvensional. Penelitian Diwu dan Ogunniyi (2010) juga melaporkan bahwa kualitas argumen siswa yang belajar menggunakan DAIM cenderung mengalami peningkatan. Hal ini terjadi karena melalui DAIM, siswa didorong untuk belajar sebagian besar melalui keterlibatan aktif mereka sendiri dalam berargumentasi, sehingga memungkinkan bagi mereka untuk menemukan konsep-konsep oleh mereka sendiri.

Tujuan dari penelitian ini adalah: (1) mendapatkan gambaran tentang peningkatan pemahaman siswa yang meliputi kemampuan menjelaskan, mencontohkan, menafsirkan, membandingkan, dan menyimpulkan, serta (2) mendapatkan gambaran tentang peningkatan kemampuan argumentasi siswa berupa kemampuan mengajukan klaim, menyertakanbuktiataudata,sertamemberikan alasan pembenaran atau dukungan, sebagai efek penerapan pembelajaran menggunakan DAIM pada materi listrik statik.

\section{METODE}

Penelitian ini menggunakan metode preexperiment. Metode pre-experiment dipilih karena tujuan penelitian ini adalah untuk mengetahui dampak dari DAIM terhadap peningkatan pemahaman dan kemampuan argumentasi siswa. Desain penelitian yang digunakan yaitu one group pretest posttest. Desain ini hanya menggunakan satu kelompok eksperimen tanpa ada kelompok pembanding. Populasi dalam penelitian ini adalah seluruh siswa kelas XII IPA semester satu di salah satu Sekolah Menengah Atas di kabupaten Majalengka. Pembagian siswa pada masing-masing kelas telah dilakukan sedemikian sehingga proporsi jumlah siswa yang memiliki kemampuan akademik tinggi, sedang maupun kurang dalam setiap kelas hampir sama antara satu kelas dengan kelas lainnya. Sampel yang diambil adalah salah satu kelas yang dipilih secara acak.

Langkah-langkah yang dilakukan pada tahap persiapan adalah menentukan masalah yang dikaji, studi literatur, studi kurikulum, menyusun silabus, RPP, lembar kerja, menyusun instrumen penelitian, meminta pertimbangan (judgement) instrumen kepada ahli, melakukan ujicoba dan menganalisis hasil ujicoba instrumen. Pada tahap pelaksanaan, kegiatan yang dilakukan adalah memberikan tes awal (pretest), perlakuan (treatment) sebanyak dua pertemuan, dan memberikan tes akhir (posttest). Kegiatan yang dilakukan pada tahap akhir penelitian adalah menganalisis hasil pretest dan posttest, mem-bandingkan sejauh apa peningkatan pemahaman dan kemampuan argumentasi siswa sebelum dan setelah penerapan pembelajaran DAIM, memberikan simpulan dan saran terhadap hasil yang telah diperoleh.

Instrumen yang digunakan pada penelitian ini adalah: (1) Testertulis yang terdiri dari tes pemahaman dan argumentasi siswa, serta tes lisan. Tes tertulis diberikan dua kali berupa pretest yang dilakukan sebelum penerapan DAIM berlangsung dan posttest yang dilakukan setelah pembelajaran DAIM berlangsung.(2) Instrumen non-tes berupa lembar observasi aktivitas guru dan siswa serta wawancara. Lembar observasi aktivitas guru dan siswa digunakan untuk melihat sejauh apa keterlaksanaan DAIMoleh guru dan siswa. Observasi ini dilakukan oleh observer. Sedangkan wawancara dilakukan untuk mengetahui tanggapan siswa terhadap penerapan DAIM. 


\section{HASIL DAN PEMBAHASAN}

Berdasarkan Gambar 1 tampak bahwa pemahaman siswa mengalami peningkatan.
Perolehan skor rata-rata N-gain pemahaman siswa sebesar $61,36 \%$. Perolehan skor ratarata $\mathrm{N}$-gainpemahaman siswa termasuk ke

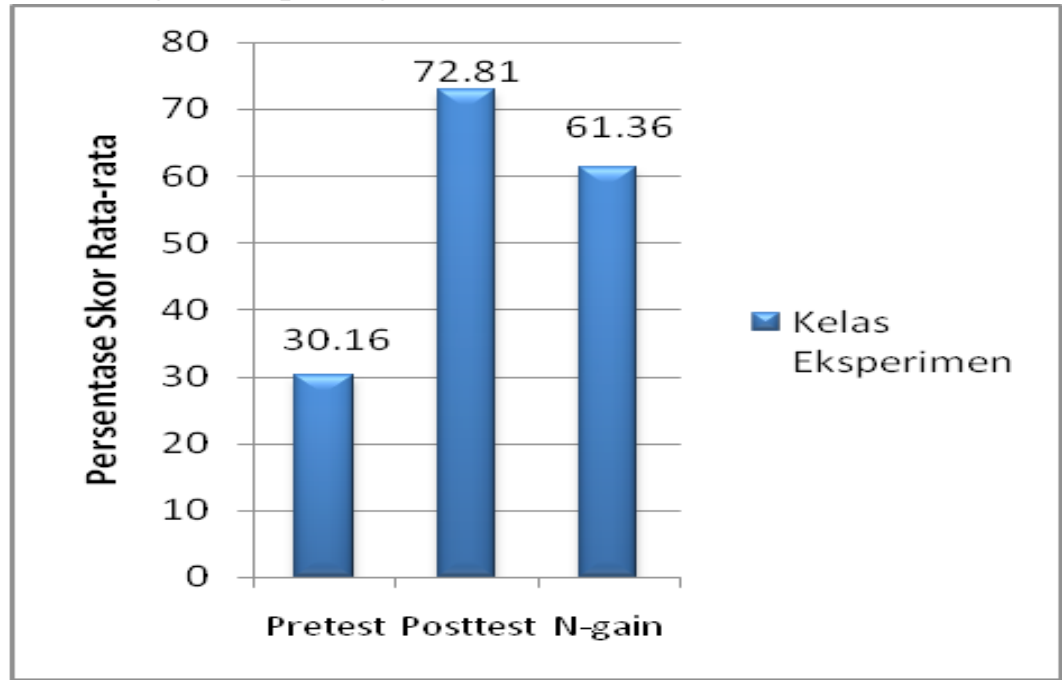

Gambar 1.

Persentase skor rata-rata pretest,posttest, dan $\mathrm{N}$-gainPemahaman Siswa

dalam kriteria sedang.

Rekapitulasi pencapaian persentase rata-rata pretest, posttest, dan $N$-gain setiap aspek pemahaman siswa disajikan pada Gambar 2. Gambar 2 memperlihatkan seluruh aspek pemahaman mengalami peningkatan ke dalam kategori sedang. Hal ini tidak lepas dari proses pembelajaran yang telah dilakukan, yaitu pembelajaran dengan menerapkan DAIM. DAIM dapat meningkatkan

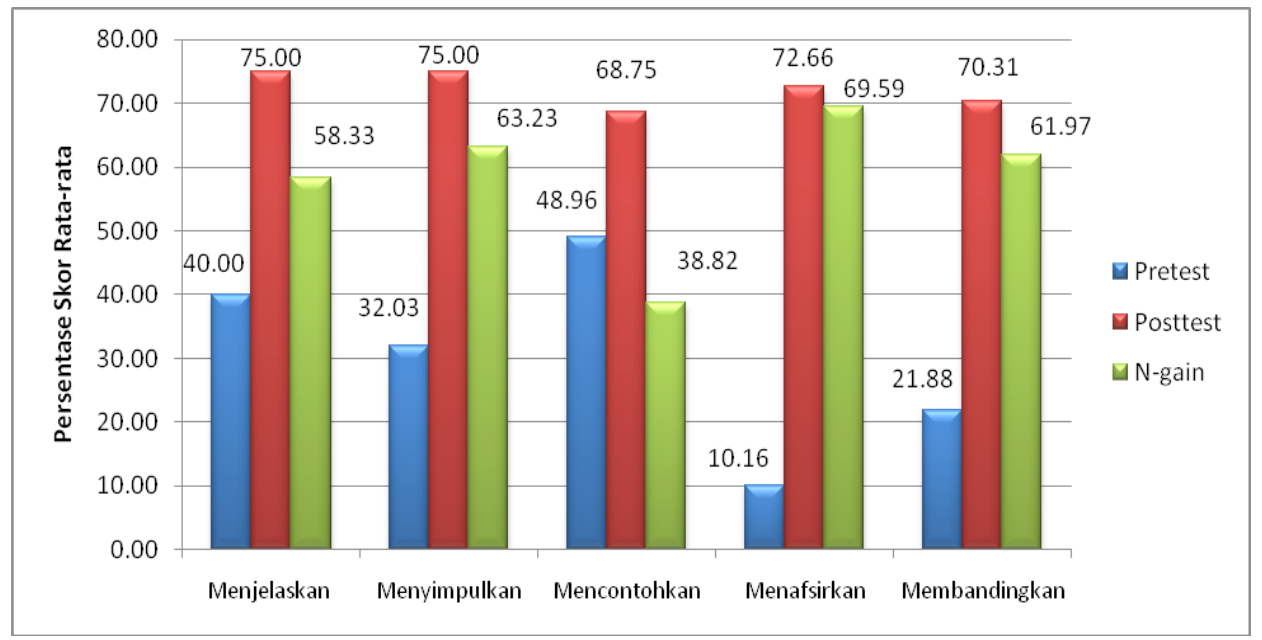

Gambar 2.

Skor Rata-rata Pretest, Posttest, dan N-gain Siswa pada Setiap Aspek Pemahaman

pemahaman siswa dikarenakan tahap-tahap pembelajaran model ini memungkinkan siswa untuk melatih kemampuan memahaminya. Pembekalan kemampuan menjelaskan dilakukan melalui kegiatan pembelajaran tahap tugas individu. Siswa diarahkan untuk menulis klaim mereka secara individu berupa jawaban permasalahan. Jawaban mereka diharapkan mengarah pada penyelesaian permasalahan. Klaim ini harus disertai bukti yang mendukung. Siswa juga harus menyertakan alasan yang menghubungkan antara bukti dan klaim. Tahap ini bertujuan untuk melatih siswa menyusun penjelasan setelah argumen mereka dapat dibuktikan kebenarannya melalui aktivitas penyelidikan dan pengumpulan data. 
Pembekalan kemampuan mencontohkan terjadi pada tahap tugas individu. Untuk dapat menemukan contoh, siswa digiring pada aktivitas penyelidikan dan pengumpulan data. Dalam mengumpulkan bukti atau data argumentasi, siswa berupaya mencari informasi seluas-luasnya dengan cara menemukan contoh-contoh yang relevan terhadap klaim yang diajukan.

Aspek menafsirkan mengalami peningkatan paling tinggi. Pada tahap dialog argumentasi kelompok, siswa berdiskusi dengan teman sekelompoknya dan memperoleh kesempatan seluas-luasnya untuk berlatih mengubah informasi dari satu bentuk ke bentuk lain. Dengan adanya kesempatan untuk berdialog secara terbuka, siswa tidak segan untuk bertanya dan berdiskusi dalam upaya mengolah setiap informasi yang ada, lalu mengubahnya ke dalam bentuk yang lain. Melalui cara-cara seperti ini, siswa terbiasa mengolah informasi dan menyajikannya ke dalam bentuk yang lain. Hal inilah yang menyebabkan kemampuan menafsirkan siswa mengalami peningkatan rata-rata gain yang paling tinggi dibandingkan dengan aspek pemahaman yang lain.

Kemampuan membandingkan dilakukan pada tahap dialog argumentasi kelas. Siswa membandingkan data yang diperoleh kelompoknya dengan data yang berasal dari kelompok lain. Ketika terjadi perbedaan data yang diperoleh, mereka terpancing untuk saling mempertanyakan dan mengungkapkan argumen masing-masing secara terbuka, hingga penyebab dari perbedaan data tersebut teridentifikasi.

Kemampuan menyimpulkan dilatihkan pada siswa dalam tahap dialog argumentasi kelas. Berdasarkan tujuannya, DAIM berupaya menciptakan suatu kegiatan diskusi argumentasi di kelas, di mana siswa melakukan dialog dengan siswa lain maupun dengan guru, agar tercapainya kesepakatan (konsensus) seluruh kelas terhadap penyelesaian permasalahan bersama (Hlazo dan Ogunniyi, 2014). Atas dasar itu, pada tahap akhir pembelajaran, siswa dituntut untuk dapat menyimpulkan penyelesaian masalah dan mengintegrasikannya dengan pengetahuan atau materi yang dipelajari.

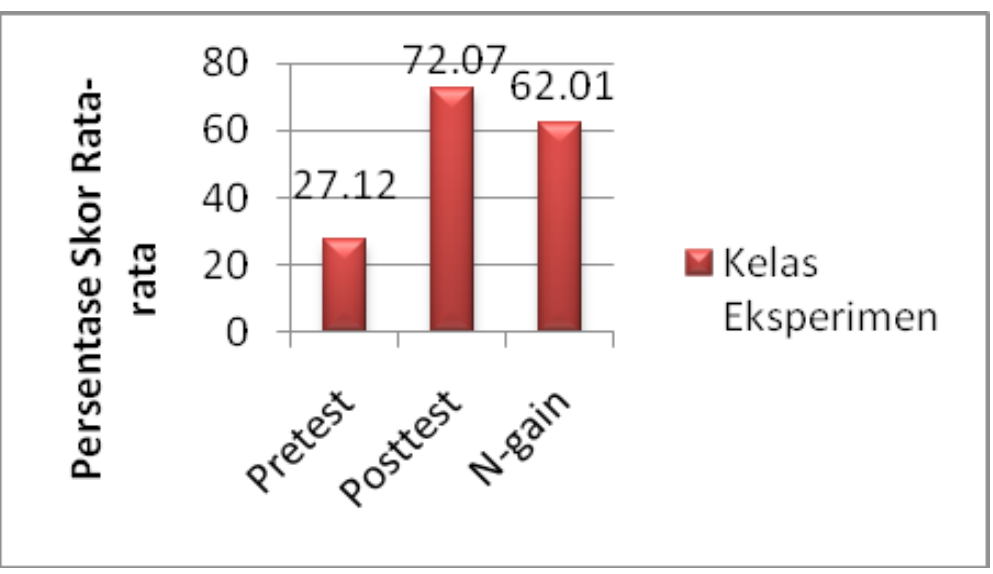

Gambar 3.

Persentase skor rata-rata pretest,posttest, dan N-gainKemampuan Argumentasi Siswa

Berdasarkan Gambar 3, perolehan skor ratarata $\mathrm{N}$-gain kemampuan argumentasi sebesar $62,01 \%$. Perolehan skor rata-rata $\mathrm{N}$-gain kemampuan argumentasi termasuk ke dalam kriteria sedang.

Untuk mengajukan sebuah klaim dan alasan yang meliputi data, pembenaran, dan dukungan, seorang siswa harus memiliki pemahaman yang baik terhadap konten materi. Semakin baik pemahaman yang dimiliki siswa, maka argumentasi sains yang dibuat juga semakin baik. Hal ini merujuk pada pendapat Kaya, dkk. (2010) yang menyatakan bahwa keterlibatan siswa dalam diskusi argumentasi dipengaruhi oleh 
pemahamannya terhadap sains. Oleh sebab itu, semakin baik pemahaman yang dimiliki siswa, maka akan memudahkan siswa tersebut dalam membangun argumentasi ilmiahnya.

Berikut ini sampel soal dan jawaban siswa pada soal pretest dan posttest mengenai argumentasi yang ditulis. Pemilihan sampel didasarkan pada pola jawaban mayoritas siswa yang hampir sama. Contoh soal :

Dua buah muatan titik positif $q_{1}=+50 \mu \mathrm{C}$ dan $q_{2}=+1 \mu \mathrm{C}$, terpisah pada jarak $1 \mathrm{~m}$. Manakah yang lebih besar, gaya yang diberikan $q_{1}$ pada $q_{2}$ atau gaya yang diberikan $q_{2}$ pada $q_{1}$ ?

Sampel jawaban siswa pada saat pretest :

Klaim:

Gaya yang diberikan oleh $q_{1}$ pada $q_{2}$ lebih besar dari pada gaya yang diberikan oleh $q_{2}$ pada $q_{1}$.

Data :

$q_{1}=+50 \mu C$

$q_{2}=+1 \mu C$

$r=1 m$

Gaya yang diberikan $q_{1}$ pada $q_{2}$ adalah $F_{\mathrm{D}}=k \frac{q_{1} q_{2}}{r^{2}}=9 \times \mathbb{0} \frac{9 \times \mathbb{0}^{-5} \cdot 1 \times 0^{-6}}{(1)^{2}}=0, \$ \mathrm{~N}$

Pembenaran/Dukungan :
Berdasarkan analisis data, diperoleh bahwa gaya listrik yang diberikan $q_{1}$ pada $q_{2}$ adalah $5 \times 10^{-2} \mathrm{~N}$. Hal ini karena muatan $q_{1}$ lebih besar dari pada muatan $q_{2}$.

Jawaban siswa pada saat posttesKlaim :

Gaya yang diberikan oleh $q_{1}$ pada $q_{2}$ adalah sama besar dengan gaya yang diberikan oleh $q_{2}$ pada $q_{\text {l. }}$

Data :

$q_{1}=+50 \mu C$

$q_{2}=+1 \mu C$

$r=1 \mathrm{~m}$

Gaya yang diberikan $q_{2}$ pada $q_{1}$ adalah

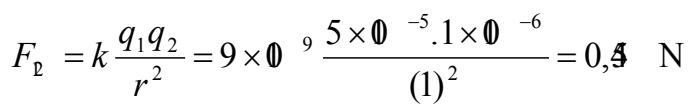

Gaya yang diberikan $q_{1}$ pada $q_{2}$ adalah

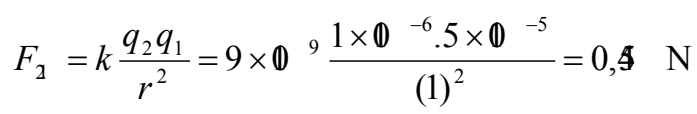

Pembenaran/dukungan:

Berdasarkan analisis data, diperoleh informasi bahwa besar gaya Coulomb pada muatan $q_{1}$ akibat muatan $q_{2}$ adalah sama dengan besar gaya Coulomb pada muatan $q_{2}$ akibat muatan $q_{1}$. Berdasarkan hukum

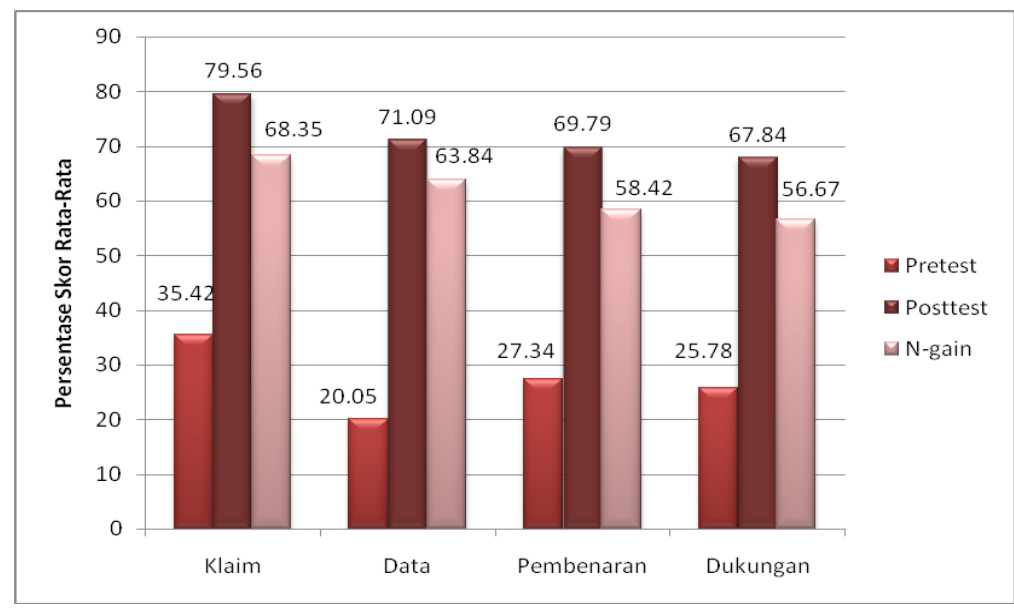

Gambar 4.

Skor Rata-rata Pretest, Posttest, dan N-gain Siswa pada Setiap Aspek Agumentasi 
Coulomb, besarnya gaya tarik atau gaya tolak pada dua muatan listrik berbanding lurus dengan muatan-muatannya dan berbanding terbalik dengan kuadrat jarak antara kedua muatan tersebut.

Perbandingan kedua jawaban pada saat pretest dan posttest menunjukkan bahwa setelah penerapan DAIM, kualitas argumentasi siswa menjadi lebih baik dibandingkan sebelumnya. Temuan ini didukung oleh penelitian Knight dan McNeill (2015) yang mengungkapkan bahwa penerapan model argumentasi membuat kemampuan argumentasi tertulis siswa menjadi lebih baik, karena siswa memiliki kesempatan yang leluasa untuk menyampaikan setiap detil penyelesaian permasalahan, baik itu penyertaan bukti atau data, alasan, maupun dukungan.

Berdasarkan Gambar 4, terjadi peningkatan kemampuan berargumentasi siswa untuk setiap indikator pada saat pretest dan posttest. N-gain pada indikator pengajuan klaim sebesar $68,35 \%$. N-gain pada indikator pengajuan data sebesar $63,84 \%$. Peningkatan indikator pemberian pembenaran dan dukungan sebesar 58,42\% dan 56,67\%.

Penyusunan argumentasi diawali dengan mangajukan klaim. Melalui kegiatan simulasi, siswa menjawab permasalahan (klaim) yang diberikan. Tujuan utama dari kegiatan simulasi adalah untuk membekali pemahaman yang digunakan sebagai dasar bagi siswa dalam berargumentasi.

Indikator lain yang dilatihkan dalam penyusunan argumentasi adalah kemampuan mengajukan data.Data-data yang diajukan oleh siswa didasarkan pada konsep serta teori-teori yang ada.Sebelum mendapatkan pemahaman, siswa belumdapat menuliskan data-data dengan benar sesuai dengan konsep dan teori. Setelah dibekali konsep, siswa baru dapat menuliskan data dengan benar sesuai dengan teori. Pengumpulan data dilakukan melalui kegiatan simulasidengan menggunakan program simulasi PhET. Setelah siswa selesai mengumpulkan data, mereka menganalisis data tersebut dan menafsirkannya ke dalam bentuk grafik atau diagram. Untuk memperoleh data terbaik hasil penyelidikan, siswa mendapatkan kesempatan melakukan diskusi pada tahap dialog argumentasi kelompok dan dialog argumentasi kelas. Data-data inilah yang kemudian mendasari mereka dalam menyusun sebuah klaim.

Kenaikan juga terjadi untuk aspek memberikan pembenaran atau dukungan. Robertshaw dan Campbell (2013) menyatakan bahwa pembenaran digunakan sebagai jembatan yang menghubungkan antara data dengan klaim. Setelah itu, diberikan dukungan untuk mendukung pembenaran yang diajukan. Oleh sebab itu, supaya klaim dan data yang diajukan akurat, maka pembenaran dan dukungan yang diajukan pun harus kuat. Kekuatan pembenaran dan dukungan didasarkan pada konsep dan teori yang digunakan. Konsep dan teori yang dimiliki siswa tidak hanya diperoleh dari buku sumber pembelajaran, tetapi juga melalui penyelidikan hubungan antar besaran pada kegiatan simulasi, sehingga konsep dan teori yang dibangun siswa menjadi lebih kuat.

Kemampuan berargumentasi dapat berkembang dengan baik pada diri siswa jika siswa dilibatkan pada kegiatan diskusi secara argumentasi (Kaya dkk., 2010). Penerapan DAIM memberikan kesempatan luas untuk berdiskusi karena kegiatan diskusi dilakukan melalui dua tahap, yaitu diskusi secara kelompok maupun seluruh kelas. Berdasarkan wawancara, diperoleh informasi bahwa pembelajaran DAIM menurut siswa :membuat mereka lebih merasa tertantang untuk berpikir,kegiatan diskusi lebih baik, karena didukung dengan data dan alasan, pemahaman siswa terhadap materi lebih mendalam, sertasiswa harus menuliskan klaim, data, pembenaran dan dukungan dengan cepat. 


\section{KESIMPULAN}

Berdasarkan hasil penelitian dan pembahasan dapat disimpulkan bahwa secara umum penerapan DAIM dapat meningkatkan pemahaman dan kemampuan argumentasi siswa hingga kriteria sedang. DAIM membuat siswa lebih merasa tertantang untuk berpikir, kegiatan diskusi lebih baik, karena didukung dengan data dan alasan, pemahaman siswa terhadap materi lebih mendalam, serta kepercayaan diri dalam berkomunikasi. Pembelajaran DAIM ini perlu lebih sering dilakukan untuk melihat besar peningkatan efektivitasnya.

\section{DAFTAR PUSTAKA}

Anderson W.L. \& Krathwohl R. D. (2001). A Taxonomy for Learning, Teaching and Assessing. A Revision of Bloom's Taxonomy of Educational Objectives. USA: Addison Wesley Longman.

Demirbag, M. \& Gunel, M. (2014). Integrating Argument-Based Science Inquiry with Modal Representations: Impact on Science Achievement, Argumentation, and Writing Skills. Educational Sciences: Theory and Practice 14(1) 386-391.

Demircioglu, T \& Ucar, S. (2012). The Effect of Argument-Driven Inquiry on PreService Science Teacher's Attitudes and Argumentation Skills. Procedia-Social and Behavioral Sciences Journal 46 (2012) 5035-5039.

Kaya, E., Erduran, S., \& Cetin P.S. (2010). High School Student's Perceptions of Argumentation. Procedia-Social and Behavioral Sciences Journal 2 (2010) 3971-3975.

Kostelnikova, M. \& Ozvoldova, M. (2013). Inquiry in Physics Classes by Means of Remote Experiments. Procedia-Social and Behavioral Sciences Journal 89 (2013) 133-138.

National Research Council. (1996). National Science Education Standards. Washington, D.C.: National Academy Press.

Ogunniyi, M. B. (2007a). Teachers' Stance and Practical Arguments Regarding A Science Indigenous Knowledge Curriculum, paper 1. International Journal of Science Education, 29 (8). 963-985.
Ogunniyi, M. B. (2007b). Teachers' Stance and Practical Arguments Regarding A Science Indigenous Knowledge Curriculum, paper 2. International Journal of Science Education, 29 (10). 1189-1207.

Osborne, J. (2010). Arguing to Learn in Science: The Role of Collaborative, Critical Discourse. American Association for the Advancement of Science, 1200 New York Avenue, Washington, DC 20005.

Passmore, C.M., \& Svoboda, J. (2012). Exploring Opportunities for Argumentation in Modelling Classrooms. International Journal of Science Education Vol. 34 No. $10,1535-1554$.

Robertshaw, B. \& Campbell, T. (2013). Constructing Arguments: Investigating Pre-Service Science Teacher's Argumentation Skills in a Socio-Scientific Context. Science Education International Journal Vol. 24, Issue 2, 195-211. 